This document is the accepted manuscript version of the following article:

McDowe11, N. G., A11en, C. D., Anderson-Teixeira, K., Aukema, B. H., Bond-Lamberty, B., Chini, L., ... Xu, C. (2020). Pervasive shifts in forest dynamics in a changing world. Science, 368(6494), eaaz9463 (10 pp.). https://doi.org/10.1126/science.aaz9463

\title{
Pervasive shifts in forest dynamics in a changing world
}

Nate G. McDowell ${ }^{1}$, Craig D. Allen ${ }^{2}$, Kristina Anderson-Teixeira ${ }^{3,4}$, Brian H. Aukema ${ }^{5}$, Ben Bond-Lamberty $^{6}$, Louise Chini ${ }^{7}$, James S. Clark ${ }^{8}$, Michael Dietze ${ }^{9}$, Charlotte Grossiord ${ }^{10}$, Adam Hanbury-Brown ${ }^{11}$, George C. Hurtt ${ }^{7}$, Robert B. Jackson ${ }^{12}$, Daniel J. Johnson ${ }^{13}$, Lara Kueppers $^{11,14}$, Jeremy W. Lichstein ${ }^{15}$, Kiona Ogle ${ }^{16}$, Ben Poulter ${ }^{17}$, Thomas A.M. Pugh ${ }^{18,19}$, Rupert Seidl ${ }^{20,21}$ Monica G. Turner ${ }^{22}$, Maria Uriarte ${ }^{23}$, Anthony P. Walker ${ }^{24}$, Chonggang Xu ${ }^{25}$

${ }^{1}$ Pacific Northwest National Laboratory, Richland, WA, 99354, USA

${ }^{2}$ US Geological Survey, Fort Collins Science Center, New Mexico Landscapes Field Station, Los Alamos, New Mexico, USA

${ }^{3}$ Conservation Ecology Center; Smithsonian Conservation Biology Institute; Front Royal, Virginia, USA

${ }^{4}$ Center for Tropical Forest Science-Forest Global Earth Observatory, Smithsonian Tropical Research Institute, Republic of Panama

${ }^{5}$ Department of Entomology, University of Minnesota, St. Paul, MN 55108, USA

${ }^{6}$ Joint Global Change Research Institute, Pacific Northwest National Laboratory, 5825

University Research Ct. \#3500, College Park, MD 20740, USA

${ }^{7}$ Department of Geographical Sciences, University of Maryland, College Park, MD 20742

${ }^{8}$ Nicholas School of the Environment, Duke University, Durham, NC 27708, USA

${ }^{9}$ Department of Earth and Environment, Boston University, Boston, MA 02215, USA

${ }^{10}$ Swiss Federal Institute for Forest, Snow and Landscape Research WSL, Zürcherstrasse 111, 8903 Birmensdorf, Switzerland

${ }^{11}$ Energy and Resources Group, University of California, Berkeley, 310 Barrows Hall \#3050, Berkeley, CA, 94720, USA

${ }^{12}$ Department of Earth System Science, Woods Institute for the Environment, and Precourt Institute for Energy, Stanford University, Stanford, CA 94305, USA

${ }^{13}$ School of Forest Resources and Conservation, University of Florida, Gainesville, FL 32611

${ }^{14}$ Division of Climate and Ecosystem Sciences, Lawrence Berkeley National Laboratory, 1 Cyclotron Road, Berkeley, CA 94720, USA

${ }^{15}$ Department of Biology, University of Florida, Gainesville, FL 32611, USA

${ }^{16}$ School of Informatics, Computing, and Cyber Systems, Northern Arizona University, Flagstaff, AZ 86001, USA

${ }^{17}$ NASA Goddard Space Flight Center, Biospheric Sciences Lab., Greenbelt, MD 20771, USA

${ }^{18}$ School of Geography, Earth and Environmental Sciences, University of Birmingham, B15 2TT Birmingham, United Kingdom;

${ }^{19}$ Birmingham Institute of Forest Research, University of Birmingham, B15 2TT Birmingham, United Kingdom; 
$37{ }^{20}$ Department of Forest and Soil Sciences, University of Natural Resources and Life Sciences

38 Vienna, Austria

$39{ }^{21}$ School of Life Sciences, Technical University of Munich, Hans-Carl-von-Carlowitz-Platz 2, $40 \quad 85354$ Freising, Germany

$41{ }^{22}$ Department of Integrative Biology, University of Wisconsin-Madison, Madison, WI 53706, 42 USA

$43{ }^{23}$ Department of Ecology, Evolution \& Environmental Biology, Columbia University, New

44 York, NY 10027, USA

$45 \quad{ }^{24}$ Environmental Sciences Division and Climate Change Science Institute, Oak Ridge National 46 Laboratory, Oak Ridge, TN 37831, USA

$47{ }^{25}$ Earth and Environmental Sciences Division, Los Alamos National Laboratory, Los Alamos, $48 \quad$ NM 87545, USA

49

50 
Enhanced abstract.

52 Background: Forest dynamics arise from the interplay of chronic drivers and transient disturbances with the demographic processes of recruitment, growth, and mortality. The resulting trajectories of vegetation development drive the biomass and species composition of terrestrial ecosystems. Forest dynamics are changing due to anthropogenic-driven exacerbation of chronic drivers, such as rising temperature and $\mathrm{CO}_{2}$, and increasing transient disturbances, including wildfire, drought, windthrow, biotic attack, and land-use change. There are widespread observations of increasing tree mortality due to changing climate and land use, accompanied by observations of growth stimulation of younger forests due to $\mathrm{CO}_{2}$ fertilization. These antagonistic processes are co-occurring globally, leaving the fate of future forests uncertain. We examine the implications of changing forest demography and its drivers as a critical uncertainty for both future forest management and forecasting impacts of global climate forcing.

Advances: We reviewed the literature of forest demographic responses to chronic drivers and transient disturbances to generate hypotheses on future trajectories of these factors and their subsequent impacts on vegetation dynamics, with a focus on forested ecosystems. We complemented this review with analyses of global land-use change and disturbance datasets to independently evaluate the implications of changing drivers and disturbances on global-scale tree demographics. Ongoing changes in environmental drivers and disturbance regimes are reducing potential carbon storage. Acclimation, adaptation, and migration may partially mitigate these effects. These increased forest impacts are due to natural disturbances (e.g. wildfire, drought, windthrow, insect/pathogen outbreaks) and land-use change, both of which are predicted to increase in magnitude in the future. Tree growth, and potentially recruitment, may have increased globally in the $20^{\text {th }}$ century based on atmospherically derived estimates of the terrestrial carbon sink and based on remote sensing data, but the growth of this carbon sink has slowed. Variability in growth stimulation due to $\mathrm{CO}_{2}$ fertilization is evident globally, with observations and experiments suggesting that forests benefit from $\mathrm{CO}_{2}$ primarily in early stages of secondary succession. Furthermore, increased tree growth typically requires sufficient water and nutrients to take advantage of rising $\mathrm{CO}_{2}$. Collectively, the evidence reveals that it is highly likely that tree mortality rates will continue to increase while recruitment and growth will respond to changing drivers in a spatially and temporally variable manner. The net impact will be a reduction in forest canopy cover and biomass.

Outlook: Pervasive shifts in forest vegetation dynamics are already occurring and are likely to accelerate under future global changes, with consequences for biodiversity and climate forcing. This conclusion is robust with respect to the abundant literature evidence and our global assessment of historical demographic changes, but it also forms the basis for hypotheses regarding the patterns and processes underlying the shifts in forest dynamics. These hypotheses will be directly testable using emerging terrestrial and satellite-based observation networks. The existing evidence and new observations provide a critical test of Earth system models that continue to improve in their ability to simulate forest dynamics and resulting climate forcing. 
92 Ultimately, forest managers and natural resource policies must confront the consequences of 93 changing climate and disturbance regimes to ensure sustainable forests and accrue their 94 associated benefits. 
96 Abstract: Forest dynamics arise from the interplay of environmental drivers and disturbances

97 with the demographic processes of recruitment, growth, and mortality, subsequently driving the 98 biomass and species composition of terrestrial ecosystems. However, forest disturbances and

99 subsequent recovery are shifting with global changes in climate and land use, altering forest

100 dynamics. Ongoing changes in environmental drivers, land use, and disturbance regimes are

101 forcing forests towards younger, shorter stands. Rising $\mathrm{CO}_{2}$, acclimation, adaptation, and

102 migration can influence these impacts. Recent developments in Earth system models support

103 increasingly realistic simulations of vegetation dynamics. In parallel, emerging remote sensing

104 datasets promise qualitatively new and more abundant data on the underlying processes and 105 consequences for vegetation structure. When combined, these advances hold promise to improve 106 the scientific understanding of changes in vegetation demographics and disturbances. Pervasive 107 shifts in forest dynamics are already occurring and are likely to accelerate under future global 108 changes, with consequences for climate forcing. 


\section{Introduction}

The interplay of vegetation demography—recruitment, growth, and mortality—with environmental conditions and disturbances drives forest dynamics of biomass, function, and species composition (Figure 1; see Box 1 for definitions). In old-growth forests that approximate steady-state demographics, the recruitment, growth, and mortality of trees are approximately balanced; in contrast, rapid recruitment often follows widespread disturbance-induced mortality (1). Vegetation dynamics may now be changing because the environmental context in which plant demography and disturbances interact is shifting with anthropogenic change (Figure 1). The interaction between episodic forest disturbances such as wind-throw or wildfire, and chronically changing drivers such as rising temperature, vapor pressure deficit $(V P D)$, and $\mathrm{CO}_{2}$, together with land-use change (2), leads to both compounding and antagonistic impacts that alter demographic rates (3), with consequences for terrestrial biogeochemical cycles and climate $(4,5)$. Understanding the drivers of vegetation dynamics is thus critical for accurate prediction of global terrestrial biogeochemistry under future conditions (6).

The impacts of global change on forest demographic rates may already be materializing. In mature ecosystems, tree mortality rates have doubled throughout much of the Americas and in Europe over the last four decades (7-9). Simultaneously, global carbon budgets indicate either a growing or constant terrestrial carbon sink (10-12), which implies increased or constant vegetation production rates $(13,14)$. However, satellite evidence suggests that forests might be switching from a $\mathrm{CO}_{2}$ fertilization dominated period to a $V P D$ dominated period (15). Terrestrial greening indices indicate a shift from a $\mathrm{CO}_{2}$-driven increase in greenness in the late $20^{\text {th }}$ century to a $V P D$-driven decrease in the last decade (16). Thus, increasing mortality due to anthropogenic changes, along with potentially increasing or stable growth and recruitment due to 
$133 \mathrm{CO}_{2}$ fertilization (5), represent opposing processes that are co-occurring globally, leaving the fate 134 of future forests uncertain.

Beyond changing vegetation dynamics within "intact" or relatively undisturbed forests, episodic disturbances are tending to be larger, more severe and, in some regions, more frequent

137 under global change(17-20). Similarly, the rates and types of land-use change (LUC) vary widely 138 (21) but have, on average, increased globally in the past few centuries $(2,22,23)$. Thus, at the global scale, disturbances and $L U C$ have likely amplified tree mortality beyond that suggested by the doubling of background mortality rates in undisturbed forests (7-9). Current understanding of the net balance of tree losses (mortality) and gains (recruitment and growth) under a changing

142 environment characterized by more extreme drivers and disturbances is limited, preventing 143 prediction of whether recruitment and growth can balance increased mortality rates in the future.

To evaluate whether environmental changes and increasing disturbances are causing globally widespread shifts in vegetation demography, we reviewed global observations of

146 recruitment, growth, and mortality of forests and woodlands. Our expert-derived compilation of 147 the state-of-the-art knowledge on vegetation dynamics, their drivers, and disturbances, allowed 148 us to address four questions: i) Is there evidence for shifts in demography over recent decades? ii) What physiological and disturbance-mediated processes underlie these demographic shifts? iii) What are the potential consequences of disturbance-mediated changes in demography for 151 climate forcing? iv) How can global predictions of future vegetation dynamics best be improved?

\section{Evidence for changing drivers and disturbances and their impact on demography.}


now enable a more complete picture of disturbances and forest demography (24-26). In this section, we first examine if there are global trends in stand ages and test the sensitivity of the stand-age distribution to changes in disturbance rate using global datasets on $L U C$ (27) and nonLUC $(25,28)$ disturbances. We subsequently draw upon the wealth of published studies on changes in forest demographics and their drivers to investigate the potential changes leading to global age-trends. Ultimately, the combination of our global estimates along with the large literature base allows us to generate testable hypotheses regarding trends and impacts of the drivers of forest demographics.

\section{Is disturbance changing forest demography at the global scale?}

We re-analysed the Land-use Harmonization ( $L U H v 2)$ dataset (28) with respect to forest age, revealing that the area of young forest stands (here defined as < 140 years old) resulting directly from $L U C$ (conversion of forest to non-forest) or wood harvest (reduction of biomass and age but retained as forest) has increased from 4.8 million $\mathrm{km}^{2}$ in 1900 to 12.5 million $\mathrm{km}^{2}$ in 2015 (or from $11.3 \%$ to $33.6 \%$ of forest area; Figure $2 \mathrm{~A}$ ). The results were insensitive to assumptions regarding the link of disturbance likelihood to stand age (Figure 2A). These forest stand age distributions exhibit different trajectories in different regions. Tropical forests have progressively lost old-growth area due to $L U C$ over the $20^{\text {th }}$ century (Figure 3 a, black dashed line). Wood harvest has increased from a minor driver of tropical forest age distribution in 1900 to a major one in 2015 (difference between solid and dashed lines). The split between deforestation and shifting cultivation drivers is broadly consistent with a satellite-based analysis for the period 2001-2015 (29). Temperate and Mediterranean forest ages are strongly influenced by wood harvest, which has made old-growth forests increasingly scarce in these regions. Boreal 
179 forests saw little influence of $L U C$ on stand age, but wood harvest has substantially shifted the 180 age distribution towards young forests.

In reality, old-growth forest are scarcer than that due to $L U C$ and wood harvest (Figures 182 2a and 3), due to other disturbances that have shifted landscapes from old- to young-dominated 183 stands (14), such as wildfire (29), windthrows (30), and biotic outbreaks (31). To address these 184 additional disturbances, we integrated recent observation-based estimates of non- $L U C$ 185 disturbance for closed-canopy forests $(25,28)$ with $L U C$ from $L U H v 2$, to obtain a first principles 186 estimate of the combined effect of human and natural disturbances on forest age structure (Figure 187 2B). A twofold increase in non- $L U C$ disturbance rates over the period 2015-2050 would result in 188 a substantial increase in the fraction of young forests (Figure 2B, C). Thus, realistic shifts in 189 disturbance rates can have substantial impacts on the age structure of forests in the future. As 190 discussed below, such an increase in disturbance rate is consistent with the magnitude of changes 191 observed or predicted in individual ecosystems.

Notably, calculations based on the Global Forest Age Dataset (GFAD) v1.1 (14,32) 193 yielded 16.5 M km2 old-growth and 26.3 M km2 of young forest (32), which differs from that in 194 Figure (2B, C). This disparity is likely attributable to consideration of different forest types 195 (closed-canopy versus all forests) and to differences in definition of stand size and age used in 196 inventories versus used in satellite-based estimates

197 Chronically changing drivers: Atmospheric $\boldsymbol{C O}_{2}$ has risen more than $125 \mathrm{ppm}$ since the 198 industrial revolution (11), and is projected to rise an additional 50 to 200 ppm by 2100 . Higher $199 \mathrm{CO}_{2}$ increases leaf-level water use efficiency, and rising $\mathrm{CO}_{2}$ has positive but uncertain 200 feedbacks on plant demographic rates (Figure 4A-B). Maturation and seed production can be 201 accelerated under elevated $\mathrm{CO}_{2}$ (33); however, seedling growth is not always stimulated by $\mathrm{CO}_{2}$ 
202 (34). Recruitment response to rising $\mathrm{CO}_{2}$ is variable $(35,36)$. Forest inventory and tree-ring

203 studies show limited evidence for $\mathrm{CO}_{2}$ fertilization of growth (37-43), potentially due to the 204 overwhelming influence of increasing drought and nutrient limitations (44). Ecosystem-scale

$205 \mathrm{CO}_{2}$ enrichment experiments in young forests suggest a 30\% gain in decadal biomass increment 206 (45), but experiments in mature forests have found minimal growth stimulation (46,47). This is 207 consistent with evidence for an initially strong $\mathrm{CO}_{2}$-related growth stimulation in young forests 208 that decreases with tree age and $\operatorname{size}^{39}$ due perhaps to nutrient $(7,48)$ and hydraulic path-length 209 limitations (49).

210 Limited studies suggest elevated $\mathrm{CO}_{2}$ causes increased mortality or no change in 211 mortality. Mortality rates of saplings during experimental drought were not mitigated by 212 elevated $\mathrm{CO}_{2}(50,51)$ while accelerated self-thinning due to $\mathrm{CO}_{2}$ fertilization-induced stand 213 density increases may lead to higher mortality (6,52,53) (Figure 4B). The latter process would 214 be consistent with increases in recruitment at large scales. Because tree mortality is dominated 215 by large size classes i.e. (54) (for details see section on size-related mortality below) faster 216 growth via $\mathrm{CO}_{2}$ fertilization may expose trees to size-related mortality risks earlier (7). Such

$217 \mathrm{CO}_{2}$-induced increases in mortality may be global (55). Furthermore, faster growth is often 218 associated with lower wood density (56), rendering fast growing trees more susceptible to high 219 winds. Thus, future $\mathrm{CO}_{2}$ fertilization could increase recruitment, growth, and mortality (Figure 220 4B), though there is significant uncertainty about these effects.

222 Chronically changing drivers: Temperature and vapor pressure deficit are rising globally and

223 will continue to rise into the future (57). Both temperature and VPD can have impacts on 224 demographic rates. Rising temperature forces an exponential rise in $V P D$, which prompts 
225 stomatal closure and limits photosynthesis, leading to lower growth, higher mortality (58), and 226 reduced regeneration (59), and ultimately driving community shifts $(60,61)$. These observations

227 are consistent with hydraulic theory, which suggests that as VPD rises, potential maximum tree

228 height declines (62) (Figure 5). This results from the dependency of water transport limitations

229 on tree size (49) that are exacerbated by elevated VPD (Figure 5), making short stature

230 advantageous with rising VPD. Because most plants cannot reduce their size (beyond limited

231 reductions in leaf area or crown dieback), forests respond through increased mortality of large

232 plants, which are replaced by smaller ones (62), as has been observed in many studies $(26,54)$.

233 While rising air temperature may also increase respiratory carbon loss, leaving less carbon for

234 growth (63), warming in wetter and cooler regions may actually stimulate reproductive output,

235 recruitment, and growth (64-66). Changes in temperature and VPD also can produce asynchrony

236 in floral and pollinator phenology (67) and can reduce cold stratification (68), both of which

237 reduce seed abundance (69), and negatively affect recruitment (70,71). Sapling mortality is

238 accelerated by elevated temperature (71,72), but recruitment has increased in moist areas (73).

239 Thus, rising temperature and VPD may be beneficial in cooler or wetter areas, but most evidence

240 suggests negative impacts on plant demographic rates (Figure 4C, D; Figure 5).

241

242 Changing disturbance regimes: Droughts are anticipated to increase in frequency, duration,

243 and severity globally (Figure 4E-F) and are more stressful to plants due to increases in

244 temperature, $V P D$, and associated water loss (57). Drought can directly cause tree death or

245 indirectly lead to mortality through associated increases in insect or pathogen attack (51).

246 Hydraulic failure and carbon starvation remain the most likely, mutually inclusive, underlying

247 physiological mechanisms for drought-induced mortality (74) and both processes are likely to

248 increase tree susceptibility to biotic agents (75). Evidence suggests that drought-induced 
mortality occurs more rapidly under warmer conditions (51.72). Consistent with these empirical results, models suggest far greater mortality of temperate conifer trees in the future (76). Reproductive output is often reduced by drought (but see (64)), which combined with drought impacts on seedling survival, leads to reduced recruitment (77). However, growth was relatively stable across a drought in Amazonia (78), while mortality increased. Thus, like rising temperature and $V P D$, it appears that drought may increase mortality regardless of location, while having variable impacts on recruitment and growth (Figure 4F).

\section{Changing disturbance regimes: Land-use change and forest management have reduced} vegetation stature and biomass, and altered species composition, with profound consequences for forest dynamics (Figures 2A, 4G-H). Today's global vegetation biomass stocks may amount to only $\sim 50 \%$ of their potential due to $L U C$ (79). Wood harvest and shifting cultivation are the land-use activities primarily responsible for the conversion from primary to secondary vegetation cover and associated demographic shifts (2). For systems that return to wild-vegetation or to managed forest after human clearing, demographic rates are typically accelerated. The increased resource availability after forest removal facilitates establishment of early-successional species, reduces species diversity $(80,81)$, and causes a transition to younger, smaller plants (82). Postdeforestation recruitment is often prolific even in the absence of management (83). Globally, the recovery of harvested forests and abandoned agricultural land, along with establishment of new plantations, has resulted in younger forests (Figure 2A), with associated reductions in tree size and biomass (84). Such post-deforestation recruitment may be limited by elevated VPD or drought, as is the case with recruitment following all natural disturbances. Overall the net effect 
271 of historical $L U C$ and wood harvest has resulted in a substantial loss of forest area, along with

272 altered demographic rates, leading to younger, shorter, less diverse ecosystems (Figure 4H).

273

274 Changing disturbance regimes: Wildfire is increasing in many forests worldwide (85) (Figure

2754 I), although human management of landscapes has led to wildfire suppression in some biomes

276 (86). Given sufficient fuel, burned area increases exponentially with aridity (87), and future fire

277 frequencies may exceed those documented over the past 10,000 years (88). Increased fire

278 activity causes increased mortality and potentially higher recruitment and growth of either pre-

279 existing or new species, but rates of recruitment and growth may be slowed under climate

280 warming. Forests characterized by stand-replacing fire regimes are dominated by obligate

281 seeders, and typically have effective seedling recruitment (89). However, high-severity and high-

282 frequency fires can reduce recruitment by reducing seed supply through the repeated and severe

283 loss of reproductively mature vegetation (90), and high frequency fires can cause recruitment

284 losses via direct mortality of the seedbank, seedlings, and saplings (91), which is worsened by

285 elevated VPD (92). Woody species that can resprout following fire, including shrubs that

286 suppress tree regeneration (92), may be favored by increased fire frequency and severity.

287 Increased fire severity results in high tree mortality in forests historically adapted to low-severity

288 fires, and subsequent recruitment and growth may be slow or absent, resulting in conversion of

289 forests to low-biomass ecosystems (93). Thus, wildfire can result in higher demographic rates,

290 though rising temperature and VPD can negatively impact recruitment and growth (Figure 4J).

292 Changing disturbance regimes: Wind throw from cyclonic storms represents the dominant

293 natural disturbance in coastal forests across the globe (94). Cyclonic storms are expected to 
294 increase in frequency, wind velocities, and precipitation intensity (95) (Figure 4K), with more

295 extreme flooding that promotes tree instability. Wind throw also results from convective

296 thunderstorms and topographically mediated winds, and warming is expected to increase the

297 frequency of atmospheric conditions conducive to severe thunderstorms (96). Canopy damage

298 and whole-tree mortality are the most immediate impacts of wind throw (97) (Figure 4L). Larger

299 trees dominate mortality from storms (98), and the loss of large canopy trees during wind

300 disturbance favors growth of surviving trees $(98,99)$ and advances regeneration, recruitment of

301 early successional species (100), or resprouting of trees broken by wind (101). Depending on the

302 resprouting or seeding capacity of surviving species, wind damage may slow or accelerate

303 succession (102). We note that storms may also be associated with lightning, which may be a

304 significant cause of large-tree mortality (103). Thus, windstorms should result in changes in all

305 three demographic rates, though with large uncertainty at the global scale (Figure 4L).

307 Changing disturbance regimes: Biotic agents Biotic disturbances from insects, insect-pathogen

308 complexes, and other biotic agents have been increasing in frequency, severity, and extent in

309 recent decades $(17,104,105)$ (Figure 3M). Such trends reflect a changing climate (106), altered

310 land use (107), and introductions of non-indigenous insects and pathogens (108). Climate change

311 is expected to further amplify biotic disturbances (109) in part through enhanced host

312 vulnerability (Figure 4M). However, shifts in frequency or dampening of disturbance regimes

313 could also emerge (110), leading to some uncertainty in outbreak dynamics under future

314 conditions (Figure 4M). While insects and associated pathogens are globally widespread, lianas,

315 or vines that use other plants as host structures, are increasing in abundance and are thought to be

316 causing increasing mortality in the tropics $(7,111)$. 
Response of insects and pathogens to climate change is likely to increase plant mortality

318 (4), with variable impacts on growth and recruitment (Figure 4N). Tree mortality can result from 319 girdling of the phloem and xylem by bark beetles (75) and from repeated defoliation events that 320 exhaust the capacity of trees to recover (112). Tree mortality during outbreaks is usually partial 321 at the stand-level because many biotic agents preferentially attack trees of specific size- or

322 health-classes, or are host-specific (16). Suppressed, smaller trees and non-host tree species may 323 survive and grow rapidly when released from competition for resources $(113,114)$. Thus, similar 324 to many other disturbances, mortality increases while recruitment and growth show variable 325 responses to biotic disturbances, including a dependency on post-disturbance temperature, $V P D$, 326 and drought.

On size and age demographics. The combination of $L U C$, disturbances, and chronic drivers is

329 likely to have already shifted forests to younger and shorter stands, with these impacts increasing 330 under expected future changes in drivers and disturbances (Figure 2A-C). These results are consistent with our review of the literature (Figure 4). Large trees are the most susceptible to die 332 from $L U C$-caused forest fragmentation $(115,116)$, drought (26), rising temperature or $V P D$ $333(54,62)$ (Figure 5), windthrow (117,118), biotic attacks (119), and lightning (103), with variable 334 size-impacts of fire (120). The abundance of size-dependent mortality drivers and disturbances 335 should logically push stands towards younger/smaller distributions of trees and shorter statured 336 species assemblages (121). There are exceptions to the pattern of climate drivers and disturbances reducing tree 338 height and stand age. Non-stand-replacing fires that kill smaller trees and leave the larger, older trees will shift forests towards larger size distributions. Similarly, on occasions when droughts 
340 preferentially kill younger but fast-growing trees, this would impact the subsequent size

341 distribution and rate of carbon accumulation. Rising $\mathrm{CO}_{2}$ and increased precipitation in some

342 areas also counter the general decrease in size because they may lead to faster growth and hence

343 taller trees (122). Thus, the antagonistic drivers promoting larger trees (e.g. rising $\mathrm{CO}_{2}$ ) vs

344 smaller trees (e.g. rising VPD, increasing disturbances) co-occur, but the general pattern of

345 decreasing size and younger ages reveals that processes driving down size and age (Figures 2-5)

346 are dominant globally.

347

348

349

The literature patterns suggest most drivers and disturbances will increase tree mortality

now and in the future, with variable effects on recruitment and growth (Figure 4). The

uncertainty grows, however, when we consider multiple feedbacks that can mitigate the changes

353 in forest demography induced by chronically changing drivers and disturbance regimes. These

354 processes include acclimation, adaptation, migration, and compensatory mechanisms of resource

355 use. With global change, forests will be influenced by a combination of phenotypic plasticity

356 (i.e. acclimation (123)), adaptation to novel biotic and abiotic stresses (124), and the ability to

357 migrate as conditions change (125). Failure to acclimate, adapt, or migrate, including due to

358 human infrastructure (126), could lead to recruitment and growth reductions and local

359 extinctions. Plants have demonstrated acclimation of phenology, seed longevity, and metabolic

360 processes to single and/or multiple stressors (127-130). Acclimation and adaptation will likely

361 depend on an array of factors including genetic variation, fecundity, dispersal, population size,

362 and environmental variability (123). Many tree species have migrated in response to past

363 climatic cycles but at rates slower than the current pace of climate change (131). Regarding 
resource use, reductions in stand density as a result of increased mortality or reduced recruitment should allow greater resource availability to surviving individuals, and therefore subsequently higher growth and survival rates (132). Such stand-resource mechanisms can manifest at the

367 landscape scale, as most disturbances are patchy (133), and the size, shape, and arrangement of 368 surviving forest patches can play a key role in recovery of the disturbed landscape (20). Taken 369 together, the mitigating factors can play a significant role in buffering the impacts of changing 370 drivers on plant survival, but it remains unclear if these factors will enable trees to keep pace 371 with ongoing climate change $(50,123)$. Ultimately, the uncertainty around future demographic 372 rates shown in Figure 3 is partially because of the influence of these mitigating factors.

\section{Consequences for community assembly and for climate forcing}

The widespread shift in vegetation dynamics begets questions regarding consequences for

377 community assembly and climate forcing. Hydraulic theory suggests that under rising VPD,

378 functional traits of high conductance, low stature, and low leaf area should best enable survival,

379 all of which are characteristics of pioneer, shrub and weed species (62). Consistent with this, 380 diversity (e.g. species richness) temporarily increases post-disturbance for many systems, as 381 short-statured, opportunistic species invade (134). If forest communities shift towards trait 382 assemblages better suited to the new disturbance regime, such shifts may confer some resistance 383 to future disturbances $(134,135)$. Alternatively, if disturbance regimes shift faster than 384 recruitment, growth, and subsequent community assembly can respond, resistance to future 385 disturbances will likely decline. 
hydrological, and land-surface energy budgets (136). Reductions in biomass result in a loss of carbon to the atmosphere despite younger, shorter stands often having higher gross photosynthesis; this is due to the loss of carbon through decomposition of necromass, which is a particularly large flux from mortality of older, larger trees such as those in old-growth forests (137), and reduced landscape-mean carbon storage under an intensified disturbance regime (138). The time required to re-achieve the same live carbon storage of an ecosystem after disturbance can be decades to centuries, particularly if the disturbance cycle is increased, thus the net effect of the biomass loss is increased $\mathrm{CO}_{2}$ to the atmosphere and hence greater climate forcing. This impact may be mitigated by increased carbon uptake due to $\mathrm{CO}_{2}$ fertilization (139) or enhanced recruitment. Calculations of the terrestrial carbon sink from atmospheric inversions 398 indicate that the sink grew over recent decades ${ }^{12}$ due in part to increased leaf area (13), consistent with increased recruitment and growth. However, evidence suggests that forests are

400 switching from a $\mathrm{CO}_{2}$ fertilization dominated period to a $V P D$ dominated period $(15,16)$, despite 401 sustained high gross photosynthesis at the global scale (140). The increased mortality

402 throughout much of the terrestrial biosphere (7-9) further minimizes potential carbon storage 403 through the enhanced biomass loss. Ultimately, the terrestrial contribution to climate forcing 404 through carbon uptake and release results from the antagonistic process of rising $\mathrm{CO}_{2}$ and forest 405 recovery from $L U C$, which enhance the carbon sink, and rising $V P D$ and disturbances that reduce 406 the carbon sink.

Changing vegetation dynamics also influence regional and global surface energy budgets and hydrological cycles. Disturbances frequently shift albedo of ecosystems from darker to 409 lighter, resulting in a decline in radiative forcing through less light absorption (141). The rate of 410 recruitment post disturbance influences the temporal period of this negative feedback (142). The 
411 impact of changing vegetation dynamics on the water cycle is particularly complex. Evaporation

412 from canopies shifts as stands become taller because taller trees transpire less (per unit leaf area)

413 than smaller trees (49), but larger trees often have better rooting access to water sources and have

414 greater total leaf area. The net effect of disturbance is a transient decrease in evaporative loading

415 to the atmosphere along with albedo shifts, causing a feedback of decreasing precipitation

416 downwind $(143,144)$. Ultimately, carbon storage is at least transiently reduced by disturbances,

417 with mixed impacts on the water and energy budgets.

\section{The path to improved prediction}

Changes in the global drivers of temperature, $\mathrm{CO}_{2}, V P D$, and disturbances including

$421 L U C$, drought, wildfire, windstorms, and insect outbreaks, should all force forests towards

422 shorter, younger, lower biomass ecosystems. This trend is supported by hydraulic theory (62)

423 (Figure 5) and by abundant empirical evidence demonstrating a consistent increase in mortality

424 across the global-spectrum of drivers and disturbances and variable but often declining

425 recruitment and growth (Figure 4). While the bulk of evidence points to reduced plant stature

426 due to changing drivers, large uncertainty remains in the magnitude and slope of demographic

427 trajectories in the future (Figure 4). Given these trajectories, and the large uncertainties around

428 them, what are the critical next steps to allow improved global prediction? Continued long-term

429 observations (ground and remotely sensed) are essential to reveal the patterns of demographic

430 responses to drivers and disturbances; likewise, manipulative experiments are needed that alter

431 conditions such as $\mathrm{CO}_{2}$ or drought to provide cause-and-effect understanding of the interactions

432 among mechanisms of demographic responses. However, for global-scale prediction of 
433 responses and climate consequences we need to mainstream insights from observations and 434 experiments into Earth system models (ESMs).

ESMs simulate the exchange of fluxes between the atmosphere, land, and ocean and stores of carbon, water, and energy; the land-surface modules of ESMs simulate the vegetation.

437 ESMs have made great progress in simulating land use, disturbances, and demography, including 438 representation of wildfire (145), drought-induced mortality (146), and cohort-age structured 439 models that enable representation of succession and associated shifts in physiological traits (6).

440 The global Coupled Model Intercomparison Projet CMIP6 now includes a dedicated model 441 intercomparison activity focused on the effects of changes of land-use on carbon and climate 442 (147). Advances in remote sensing and forest inventory integration are enhancing global 443 datasets of forest structure (148) and age (32) that can be used in model initialization, data 444 assimilation benchmarking, and sensitivity analyses (Figure 2A-C). These advancements set the 445 stage for developments in ESMs such as the prediction of disturbances and demographic rate 446 responses under climate and $L U C$ scenarios. The newest generation of ESMs utilize size or age-structured approaches to explicitly 448 model demography in the Earth system (6), which should ultimately enable model-based 449 representation of observed shifts in age structure (e.g. Figure 2). However, representation of 450 vegetation demographic rates remains relatively simplistic. Simulation of growth responses to 451 global change requires model refinement in light capture, belowground water and nutrient 452 acquisition, and responses of respiration to temperature (6). Recruitment, including reproduction 453 and dispersal, is the most undeveloped demographic process in ESM simulations. Reproductive 454 allocation is invariant with plant functional type (PFT), and seed is assumed to mix evenly 455 throughout a grid cell (but see (149)). Environmental constraints to PFT establishment are 
456 derived from prior distributions of major taxa, and while recruitment rates can be influenced by

457 light or space availability, they are not responsive to temperature, $\mathrm{CO}_{2}$, or soil moisture

458 (150,151). Simplistic dispersal assumptions are typically either overly permissive or restrictive.

459 Improvements in representing recruitment under global change are critical for improving

460 predictions of vegetation dynamics. These advancements will require data synthesis and new

461 data collection to support PFT-specific, environmentally sensitive parameterizations of

462 regeneration processes, such as reproductive allocation; effective dispersal; seedling

463 establishment, survival and growth; and post-disturbance recovery strategies (e.g., serotiny and

464 resprouting).

Disturbance-induced mortality is better developed for landscape-scale models than for

ESMs. ESM modeling of disturbance-induced mortality exists for wildfire and drought

$467(145,146)$, although significant challenges remain to represent both reliably globally, while ESMs

468 are under-developed for wind and insect mortality. Currently only one ESM to our knowledge

469 represents canopy damage (152); this causes ESMs to potentially underestimate the impacts of

470 drought and wind, as both disturbances cause lagged tree mortality associated with canopy loss

471 years after the inciting event $(153,154)$. For insects, there have been prescriptive studies

472 examining the impact of insect outbreaks on land processes within ESMs, but no ESM has yet

473 explicitly considered the interaction between plant defense and insect population dynamics for

474 prediction of large-scale insect-induced tree mortality. For predicting wildfire, models should be

475 sensitive to both fuels and climate interactions and represent spatial patterns of burn severity

476 because the burn mosaic strongly influences postfire vegetation dynamics (145). Next-

477 generation demographic models are evolving to include explicit, mechanistic representations of

478 drought-associated mortality, including carbon starvation and hydraulic failure (155). The 
479 evaluation of new hydraulics models (155) for prediction of mortality is an essential next step.

480 Ultimately, model formulations that include environmentally sensitive, $P F T$-specific processes

481 compatible with the cohort-based approach are likely to provide the best compromise between

482 process-detail and parsimony and therefore most likely to capture changes in large-scale forest

483 dynamics under future conditions.

484

485 Summary Forest vegetation dynamics (Figure 1) are already strongly influenced by global

486 change (Figure 2) and will continue to be affected in the future (Figures 2-5) by changes in land

487 use, chronic drivers such as $\mathrm{CO}_{2}$ and $V P D$, and increasing frequency and severity of transient

488 disturbances such as windthrow, wildfire, and insect outbreaks. Effects on forests are driven

489 largely by consistent increases in tree mortality from these drivers, and variable responses of

490 recruitment and growth depending on stand-age, disturbance type, and geographic location

491 (Figure 4). The consequences of changing demographics suggest an increasing constraint in

492 terrestrial carbon storage due, at least, to the consistent increase in mortality. Any declines in

493 recruitment or growth, especially when disturbance-recovery cycles are disrupted, will

494 exacerbate this carbon-cycle constraint. Shifts in other terrestrial radiative forcing terms such as

495 energy and water budgets are also likely. While well-supported by the literature, data, and

496 sensitivity analysis (Figure 2), the trends in Figure (4) represent hypotheses to be tested by the

497 next-generation of observational platforms, both terrestrial and space-borne. Forest management

498 must ultimately confront the elevated mortality and uncertainty in recruitment and growth when

499 considering options for sustaining forest benefits to society into the future. 


\section{References}

1. Turner, M. G., Whitby, T. G., Tinker, D. B. \& Romme, W. H. Twenty-four years after the Yellowstone Fires: Are postfire lodgepole pine stands converging in structure and function? Ecology 97, 1260-1273 (2016).

2. Hurtt, G. C., Chini, L. P., Frolking, S., Betts, R. A., Feddema, J., Fischer, G., et al. Harmonization of land-use scenarios for the period 1500-2100: 600 years of global gridded annual land-use transitions, wood harvest, and resulting secondary lands. Climatic Change. http://doi.org/10.1007/s10584-011-0153-2. (2011)

3. Anderson-Teixeira, K. J. et al. Altered dynamics of forest recovery under a changing climate. Glob. Chang. Ecol. 19, 2001-2021 (2013).

4. Reichstein, M. et al. Climate extremes and the carbon cycle. Nature 500, 287-295 (2013).

5. Seidl, R. et al. Forest disturbances under climate change. Nat. Clim. Change 7, 395-402 (2017).

6. Fisher, R. A. et al. Vegetation demographics in earth system models: a review of progress and priorities. Glob. Chang. Ecol. 24, 35-54 (2017).

7. McDowell, N. G. et al. Drivers and mechanisms of tree mortality in moist tropical forests. New Phytol. 219, 851-869 (2018).

8. Carnicer, J. et al. Widespread crown condition decline, food web disruption, and amplified tree mortality with increased climate change-type drought. Proc. Natl Acad. Sci. 108, 1474-1478 (2011).

9. Senf C. et al. Canopy mortality has doubled in Europe's temperate forests over the last three decades. Nat. Comm. 9, 4978 (2018).

10. Fernández-Martínez, M. et al. Global trends in carbon sinks and their relationships with $\mathrm{CO}_{2}$ and temperature. Nat. Clim. Change 9, 73-79 (2019).

11. Friedlingstein, P. et al. Global Carbon Budget 2019. Earth System Science Data 11, 17831838 (2019).

12. Ciais, P., Tan, J., Wang, X., Roedenbeck, C., Chevallier, F., Piao, S.L., Moriarty, R., Broquet, G., Le Quéré, C., Canadell, J.G. and Peng, S., 2019. Five decades of northern land carbon uptake revealed by the interhemispheric $\mathrm{CO}_{2}$ gradient. Nature, 568(7751), p.221.

13. Chen JM, W Ju, P Ciais, N Viovy, R Liu, Y Liu, X Lu, Vegetation structural change since 1981 significantly enhanced the terrestrial carbon sink. Nature Communications 10 (1), 1713.

14. Pugh, T. A. M. et al. Role of forest regrowth in global carbon sink dynamics. Proc. Natl Acad. Sci. 116, 4382-4387 (2019).

15. Peñuelas, J., Ciais, P., Canadell, J.G., Janssens, I.A., Fernández-Martínez, M., Carnicer, J., Obersteiner, M., Piao, S., Vautard, R. and Sardans, J., 2017. Shifting from a fertilizationdominated to a warming-dominated period. Nature Ecology \& Evolution, 1(10), p.1438. 
16. Yuan, W., Zheng, Y., Piao, S., Ciais, P., Lombardozzi, D., Wang, Y., Ryu, Y., Chen, G., Dong, W., Hu, Z. and Jain, A.K., 2019. Increased atmospheric vapor pressure deficit reduces global vegetation growth. Science Advances, 5(8), p.eaax1396.

17. Raffa, K. F. et al. Cross-scale drivers of natural disturbances prone to anthropogenic amplification: the dynamics of bark beetle eruptions. Bioscience 58, 501-517 (2008).

18. Tippett, M. K., Lepore, C. \& Cohen, J. E. More tornadoes in the most extreme US tornado outbreaks. Science 354, 1419-1423 (2016).

19. van der Werf, G. R. et al. Global fire emissions estimates during 1997-2016. Earth System Science Data 9, 697-720 (2017).

20. Sommerfeld, A. et al. Patterns and drivers of recent disturbances across the temperate forest biome. Nature Communications 9, 4355 (2018).

21. Houghton, R. A. \& Nassikas, A. A. Global and regional fluxes of carbon from land use and land cover change 1850-2015. Global Biogeochemical Cycles 31, 456-472 (2017).

22. Foley, J. A. et al. Global consequences of land use. Science 309, 570-574 (2005).

23. Perring, M. et al. Global environmental change effects on ecosystems: the importance of land-use legacies. Glob. Chang. Biol. 22, 1361-1371 (2015).

24. Hartmann H, Schuldt B, Sanders TGM, Macinnis-Ng C, Boehmer HJ, Allen CD, Bolte A, Crowther TW, Hansen MC, Medlyn BE, Ruehr NK, Anderegg WRL. 2018. Monitoring global tree mortality patterns and trends. Report from the VW symposium 'Crossing scales and disciplines to identify global trends of tree mortality as indicators of forest health'. New Phytologist 217: 984-987.

25. Pugh, T.A., Arneth, A., Kautz, M., Poulter, B. and Smith, B., 2019. Important role of forest disturbances in the global biomass turnover and carbon sinks. Nature Geoscience, pp.1-6.

26. Stovall, A.E., Shugart, H. and Yang, X., 2019. Tree height explains mortality risk during an intense drought. Nature Communications, 10(1), pp.1-6.

27. Hurtt G, Chini L, Sahajpal R, Frolking S (2017) Harmonization of global land-use change and management for the period 850-2100. Available at luh.umd.edu/data.shtml. Accessed October 24th, 2019.

28. Hansen, M.C., et al. 2013. High-resolution global maps of 21st-century forest cover change. Science, 342(6160), pp.850-853.

29. Curtis, P.G., Slay, C.M., Harris, N.L., Tyukavina, A. and Hansen, M.C., 2018. Classifying drivers of global forest loss. Science, 361(6407), pp.1108-1111.

30. Frolking, S. et al. Forest disturbance and recovery: a general review in the context of spaceborne remote sensing of impacts on aboveground biomass and canopy structure. $J$. Geophys. Res. 114, G00E02 (2009). 
581

582

583

584

585

586

587

588

589

590

591

592

593

594

595

596

597

598

599

600

601

602

603

604

605

606

607

31. Kautz, M., Meddens, A. J. H., Hall, R. J. \& Arneth, A. Biotic disturbances in Northern Hemisphere forests - a synthesis of recent data, uncertainties and implications for forest monitoring and modelling. Glob. Ecol. Biogeogr. 26, 533-552 (2017).

32. Poulter, B. et al. The Global Forest Age Dataset and its Uncertainties (GFADv1.1) (PANGAEA, 2019); https://doi.org/10.1594/PANGAEA.897392

33. LaDeau, S. L. \& Clark, J. S. Rising $\mathrm{CO}_{2}$ levels and the fecundity of forest trees. Science 292, 95-98 (2001).

34. Mohan, J. E., Clark, J. S., \& Schlesinger, W. H. Long-term $\mathrm{CO}_{2}$ enrichment of a forest ecosystem: implications for forest regeneration and succession. Ecol. Appl. 17, 1198-1212 (2007).

35. Perry, L. G., Shafroth, P. B., Blumenthal, D. M., Morgan, J. A. \& LeCain, D. R. Elevated $\mathrm{CO}_{2}$ does not offset greater water stress predicted under climate change for native and exotic riparian plants. New Phytol. 197, 532-543 (2013).

36. Saintilan, N. \& Rogers, L. Woody plant encroachment of grasslands: a comparison of terrestrial and wetland settings. New Phytol. 197, 1062-1070 (2015).

37. McMahon, S. M., Parker, G. G. \& Miller, D. R. Evidence for a recent increase in forest growth. Proc. Natl Acad. Sci. USA 107, 3611-3615 (2010).

38. Camarero, J. J., Gazol, A., Galvan, J. D., Sanguesa-Barreda, G. \& Gutierrez, E. Disparate effects of global-change drivers on mountain conifer forests: warming-induced growth enhancement in young trees vs. $\mathrm{CO}_{2}$ fertilization in old trees from wet sites. Glob. Chang. Biol. 21, 738-749 (2015).

39. Voelker, S. L., Muzika, R. M., Guyette, R. P. \& Stambaugh, M. C. Historical $\mathrm{CO}_{2}$ growth enhancement declines with age in Quercus and Pinus. Ecological Monogr. 76, 549-564 (2006).

40. Penuelas, J., Canadell, J. G. \& Ogaya, R. Increased water-use efficiency during the $20^{\text {th }}$ century did not translate into enhanced tree growth. Global Ecol. Biogeography 20, 597 608 (2011).

41. van der Sleen, P. et al. No growth stimulation of tropical trees by 150 years of $\mathrm{CO}_{2}$ fertilization but water-use efficiency increased. Nature Geoscience 8, 24-28 (2015).

42. Girardin, M.P., Bouriaud, O., Hogg, E.H., Kurz, W., Zimmermann, N.E., Metsaranta, J.M., et al. (2016). No growth stimulation of Canada's boreal forest under half-century of combined warming and CO2 fertilization. PNAS, 113, E8406-E8414.

43. Brienen, R.J.W., Phillips, O.L., Feldpausch, T.R., Gloor, E., Baker, T.R., Lloyd, J., et al. (2015). Long-term decline of the Amazon carbon sink. Nature, 519, 344-348.

44. Gedalof, Z. \& Berg, A. Tree ring evidence for limited direct $\mathrm{CO}_{2}$ fertilization of forests over the $20^{\text {th }}$ century. Glob. Biogeochem. Cycles 24, GB3027 (2010). 
45. Walker, A. P. et al. Decadal biomass increment in early secondary succession woody ecosystems is increased by $\mathrm{CO}_{2}$ enrichment. Nature Communications 10, 454 (2019).

46. Bader, M. K. F. et al. Central European hardwood trees in a high- $\mathrm{CO}_{2}$ future: synthesis of an 8-year forest canopy $\mathrm{CO}_{2}$ enrichment project. J. Ecol. 101, 1509-1519 (2013).

47. Ellsworth, D. S. et al. Elevated $\mathrm{CO}_{2}$ does not increase eucalypt forest productivity on a lowphosphorus soil. Nat. Clim. Change 7, 279-282 (2017).

48. Norby, R. J. et al. Net primary productivity of a $\mathrm{CO}_{2}$-enriched deciduous forest and the implications for carbon storage. Ecol. Appl. 12, 1261-1266 (2002).

49. McDowell, N. G., Bond, B. J., Dickman, L. T., Ryan, M. G. \& Whitehead, D. Relationships between tree height and carbon isotope discrimination. in Size- and Age-Related Changes in Tree Structure and Function (eds Meinzer, F. C. et al.) 255-286 (Springer, Dordrecht, 2011).

50. Duan, $\mathrm{H}$. et al. Elevated $\left[\mathrm{CO}_{2}\right]$ does not ameliorate the negative effects of elevated temperature on drought-induced mortality in Eucalyptus radiata seedlings. Plant Cell Environ. 37, 1598-1613 (2014).

51. Allen, C. D., Breshears, D. D. \& McDowell, N. G. On underestimation of global vulnerability to tree mortality and forest die-off from hotter drought in the Anthropocene. Ecosphere 6 1-55 (2015).

52. Körner, C., 2017. A matter of tree longevity. Science, 355(6321), pp.130-131.

53. Büntgen, U., Krusic, P.J., Piermattei, A., Coomes, D.A., Esper, J., Myglan, V.S., Kirdyanov, A.V., Camarero, J.J., Crivellaro, A. and Körner, C., 2019. Limited capacity of tree growth to mitigate the global greenhouse effect under predicted warming. Nature communications, 10(1), p.2171.

54. Bennett, A. C., McDowell, N. G., Allen, C. D. \& Anderson-Teixeira, K. J. Larger trees suffer most during drought in forests worldwide. Nature Plants 1, 15139 (2015).

55. Yu, K., Smith, W.K., Trugman, A.T., Condit, R., Hubbell, S.P., Sardans, J., Peng, C., Zhu, K., Peñuelas, J., Cailleret, M. and Levanic, T., 2019. Pervasive decreases in living vegetation carbon turnover time across forest climate zones. Proceedings of the National Academy of Sciences, 116(49), pp.24662-24667.

56. Pretzsch, H., Biber, P., Schütze, G., Kemmerer, J. \& Uhl, E. Wood density reduced while wood volume growth accelerated in Central European forests since 1870. For. Ecol. Manage. 429, 589-616 (2018).

57. Trenberth, K. E. et al. Global warming and changes in drought. Nat. Clim. Change 4, 17-22 (2014).

58. Williams, A. P. et al. Temperature as a potent driver of regional forest drought stress and tree mortality. Nat. Clim. Change 3, 292-297 (2013). 
59. Tepley, A. J., Thompson, J. R., Epstein, H. E. \& Anderson-Teixeira, K. J. Vulnerability to forest loss through altered postfire recovery dynamics in a warming climate in the Klamath Mountains. Glob. Chang. Biol. 23, 4117-4132 (2017).

60. Serra-Diaz, J. M. et al. Disequilibrium of fire-prone forests sets the stage for a rapid decline in conifer dominance during the $21^{\text {st }}$ century. Scientific Reports 8, 6749 (2018).

61. Uriarte, M, Lasky, J. R., Boukili, V. K. \& Chazdon, R. L. A trait-mediated, neighbourhood approach to quantify climate impacts on successional dynamics of tropical rainforests. Funct. Ecol. 30, 157-167 (2016).

62. McDowell, N. G. \& Allen, C. D. Darcy's law predicts widespread forest mortality under climate warming. Nat. Clim. Change 5, 669-672 (2015).

63. Liu, J. et al. Contrasting carbon cycle response of the tropical continents to the 2015-2016 El Niño. Science 358, eeam5690 (2017).

64. Wright, S. J. \& Calderón, O. Seasonal, El Niño and longer term changes in flower and seed production in a moist tropical forest. Ecol. Lett. 9, 35-44 (2006).

65. Anderson-Teixeira, K. J. et al. Altered dynamics of forest recovery under a changing climate. Glob. Chang. Ecol. 19, 2001-2021 (2013).

66. Keenan, T. F. \& Riley, W. J. Greening of the land surface in the world's cold regions consistent with recent warming. Nat. Clim. Change 8, 825-828 (2018).

67. Forrest, J.R., 2015. Plant-pollinator interactions and phenological change: what can we learn about climate impacts from experiments and observations?. Oikos, 124(1), pp.4-13.

68. Walck, J. L., Hidayati, S. N., Dixon, K. W., Thompson, K. \& Poschlod, P. Climate change and plant regeneration from seed. Glob. Chang. Biol. 17, 2145-2161 (2011).

69. Memmott, J., Craze, P. G., Waser, N. M. \& Price, M. V. Global warming and the disruption of plant-pollinator interactions. Ecol. Lett. 10, 710-717 (2007).

70. Kueppers, L. M. et al. Warming and provenance limit tree recruitment across and beyond the elevation range of subalpine forest. Glob. Chang. Biol. 23, 2383-2395 (2017).

71. Hansen, W. D. \& Turner, M. G. Origins of abrupt change? Postfire subalpine conifer regeneration declines nonlinearly with warming and drying. Ecological Monogr. 89, e01340 (2019).

72. Adams, H. D. et al. Temperature sensitivity of drought-induced tree mortality portends increased regional die-off under global-change-type drought. Proc. Natl Acad. Sci. 106, 7063-7066 (2009).

73. Hember, R. A. et al. Accelerating regrowth of temperate-maritime forests due to environmental change. Glob. Clim. Change 18, 2026-2040 (2012).

74. Adams, H.D., Zeppel, M.J., Anderegg, W.R., Hartmann, H., Landhäusser, S.M., Tissue, D.T., Huxman, T.E., Hudson, P.J., Franz, T.E., Allen, C.D. Anderegg, L.D., et al. 2017. A multi-species synthesis of physiological mechanisms in drought-induced tree mortality. Nature Ecology \& Evolution, 1(9), p.1285. 
75. Gaylord, M. L. et al. Drought predisposes piñon-juniper woodlands to insect attacks and mortality. New Phytol. 198, 567-578 (2013).

76. McDowell, N. G. et al. Multi-scale predictions of massive conifer mortality due to chronic temperature rise. Nat. Clim. Change 6, 295-300 (2016).

77. Engelbrecht, B. M. J. \& Kursar, T. A. Comparative drought-resistance of seedlings of 28 species of co-occurring tropical woody plants. Oecologia 136, 383-393 (2003).

78. Doughty, C.E., Metcalfe, D.B., Girardin, C.A.J., Amézquita, F.F., Cabrera, D.G., Huasco, W.H., Silva-Espejo, J.E., Araujo-Murakami, A., Da Costa, M.C., Rocha, W. and Feldpausch, T.R., 2015. Drought impact on forest carbon dynamics and fluxes in Amazonia. Nature, 519(7541), p.78.

79. Erb, K. et al. Land management: data availability and process understanding for global change studies. Glob. Chang. Biol. 23, 512-533 (2017).

80. Martin, P. A., Newton, A. C., Pfeifer, M., Khoo, M. \& Bullock, J. M. Impacts of tropical selective logging on carbon storage and tree species richness: A meta-analysis. For. Ecol. and Manage. 356, 224-233 (2015).

81. Chaudhary, A., Burivalova, Z., Koh, L. P. \& Hellweg, S. Impact of forest management on species richness: global meta-analysis and economic trade-offs. Scientific Reports 6 (2016).

82. Duveneck, M. J., Thompson, J. R., Gustafson, E. J., Liang, Y. \& de Bruijn, A. M. G. Recovery dynamics and climate change effects to future New England forests. LandscapeEcol. 32, 1385-1397 (2017).

83. Thom, D., Rammer, W., Garstenauer, R. \& Seidl, R. Legacies of past land use have a stronger effect on forest carbon exchange than future climate change in a temperate forest landscape. Biogeosciences 15, 5699-5713 (2018).

84. Vilen, T. et al. Reconstructed forest age structure in Europe 1950-2010. For. Ecol. and Manage. 286, 203-218 (2012).

85. Jolly, W. M. et al. Climate-induced variations in global wildfire danger from 1979 to 2013. Nature Communications 6, 7537 (2015).

86. Andela, N. et al. A human-driven decline in global burned area. Science 356, 1356-1361 (2017).

87. Abatzoglou, J. T. \& Williams, A. P. Impact of anthropogenic climate change on wildfire across western US forests. Proc. Natl Acad. Sci. 113, 11770-11775 (2016).

88. Westerling, A. L., Turner, M. G., Smithwick, E. A. H., Romme, W. H. \& Ryan, M. G. Continued warming could transform Greater Yellowstone fire regimes by mid-2 $1^{\text {st }}$ century. Proc. Natl Acad. Sci. 108, 13165-13170 (2011).

89. Bowman, D., Williamson, G. J., Prior, L. D. \& Murphy, B. P. The relative importance of intrinsic and extrinsic factors in the decline of obligate seeder forests. Glob. Ecol. and Biogeography 25, 1166-1172 (2016). 
90. Johnstone, J. F. et al. Changing disturbance regimes, ecological memory, and forest resilience. Frontiers in Ecol. and the Environ. 14, 369-378 (2016).

91. Turner, M. G., Braziunas, K. H., Hansen, W. D. \& Harvey, B.J. Short-interval severe fire erodes the resilience of subalpine lodgepole pine forests. Proc. Natl Acad. Sci. 201902841 (2019)

92. Tepley, A. J., Thompson, J. R., Epstein, H. E. \& Anderson-Teixeira, K. J. Vulnerability to forest loss through altered postfire recovery dynamics in a warming climate in the Klamath Mountains. Glob. Chang. Biol. 23, 4117-4132 (2017).

93. Kitzberger, T. et al. Fire-vegetation feedbacks and alternative states: common mechanisms of temperate forest vulnerability to fire in southern South America and New Zealand. New Zealand J. of Bot. 54, 247-272 (2016).

94. Lugo, A. E. Visible and invisible effects of hurricanes on forest ecosystems: an international review. Austral Ecol. 33, 368-398 (2008).

95. Balaguru, K., Foltz, G. R. \& Leung, L. R. Increasing magnitude of hurricane rapid intensification in the central and eastern tropical Atlantic. Geophys. Research Lett. 45, 4238-4247 (2018).

96. Diffenbaugh, N. S., Scherer, M. \& Trapp, R. J. Robust increases in severe thunderstorm environments in response to greenhouse forcing. Proc. Natl Acad. Sci. 110, 16361-16366 (2013).

97. Uriarte, M., Canham, C. D., Thompson, J. \& Zimmerman, J. K. A neighborhood analysis of tree growth and survival in a hurricane-driven topical forest. Ecol. Monogr. 74, 591-614 (2004).

98. Gardiner, B., Berry, P. \& Moulia, B., Wind impacts on plant growth, mechanics and damage. Plant Science, 245, 94-118 (2016).

99. Uriarte, M. et al. Natural disturbances and human land use as determinants of tropical forest dynamics: results from a forest simulator. Ecol. Monogr. 79, 423-443 (2009).

100. Comita, L.S. et al. Abiotic and biotic drivers of seedling survival in a hurricane-impacted tropical forest. J. Ecol. 97, 1346-1359 (2009).

101. Uriarte, M. et al. Multidimensional trade-offs in species responses to disturbance: implications for diversity in a subtropical forest. Ecology 93, 191-205 (2012).

102. Flynn, D. B. F. et al. Hurricane disturbance alters secondary forest recovery and introduced species dynamics. Biotropica 42, 149-157 (2010).

103. Yanoviak, S.P., Gora, E.M., Bitzer, P.M., Burchfield, J.C., Muller-Landau, H.C., Detto, M., Paton, S. and Hubbell, S.P., 2019. Lightning is a major cause of large tree mortality in a lowland neotropical forest. New Phytologist.

104. Seidl, R., Schelhaas, M. J., Rammer, W. \& Verkerk, P. J. Increasing forest disturbances in Europe and their impact on carbon storage. Nat. Clim. Change 4, 806-810 (2014). 
105. Kautz, M., Meddens, A. J., Hall, R. J. \& Arneth, A. Biotic disturbances in Northern Hemisphere forests-a synthesis of recent data, uncertainties and implications for forest monitoring and modelling. Glob. Ecol. Biogeography 26, 533-552 (2017).

106. Raffa, K.F., Aukema, B.H., Bentz, B.J., Carroll, A.L., Hicke, J.A. and Kolb, T.E., 2015. Responses of tree-killing bark beetles to a changing climate. Climate change and insect pests, 7, pp.173-201.

107. Shurman, J. S. et al. Large-scale disturbance legacies and the climate sensitivity of primary Picea abies forests. Glob. Chang. Biol. 24, 2169-2181 (2018).

108. Rosenberger, D. W., Venette, R. C. \& Aukema, B. H. Development of an aggressive bark beetle on novel hosts: Implications for outbreaks in an invaded range. J. Appl. Ecol. 55, 1526-1537 (2018).

109. Seidl, R. et al. Invasive alien pests threaten the carbon stored in Europe's forests. Nature Communications 9, 1626 (2018).

110. Johnson, D. M. et al. Climatic warming disrupts recurrent Alpine insect outbreaks. Proc. Natl Acad. Sci. 107, 20576-20581 (2010).

111. di Porcia e Brugnera, M., Meunier, F., Longo, M., Krishna Moorthy, S.M., De Deurwaerder, H., Schnitzer, S.A., Bonal, D., Faybishenko, B. and Verbeeck, H., 2019. Modeling the impact of liana infestation on the demography and carbon cycle of tropical forests. Global Change Biology, 25(11), pp.3767-3780.

112. Pureswaran, D. S., Johns, R., Heard, S. B. \& Quiring, D. Paradigms in eastern spruce budworm (Lepidoptera: Tortricidae) population ecology: a century of debate. Entomology 45, 1333-1342 (2016).

113. Virgin, G. V. J. \& MacLean, D. A. Five decades of balsam fir stand development after spruce budworm-related mortality. For. Ecol. and Manage. 400, 129-138, (2017).

114. Macek, M. et al. Life and death of Picea abies after bark-beetle outbreak: ecological processes driving seedling recruitment. Ecol. Appl. 27, 156-167 (2017).

115. Laurance, W.F., Delamônica, P., Laurance, S.G., Vasconcelos, H.L. and Lovejoy, T.E., 2000. Conservation: rainforest fragmentation kills big trees. Nature, 404(6780), p.836.

116. Lindenmayer, D.B., Laurance, W.F. and Franklin, J.F., 2012. Global decline in large old trees. Science, 338(6112), pp.1305-1306.

117. Peterson, C.J., 2000. Catastrophic wind damage to North American forests and the potential impact of climate change. Science of the total Environment, 262(3), pp.287-311.

118. Canham, C.D., Papaik, M.J. and Latty, E.F., 2001. Interspecific variation in susceptibility to windthrow as a function of tree size and storm severity for northern temperate tree species. Canadian Journal of Forest Research, 31(1), pp.1-10. 
119. Boone, Aukema, Bohlmann, Carroll, and Raffa (2011) Efficacy of tree defense physiology varies with bark beetle population density: a basis for positive feedback in eruptive species. Can J Forest Research 6: 1174-1188.

120. McDowell, N. G. et al. Predicting chronic climate-driven disturbances and their mitigation. Trends Ecol. Evol. 33, 15-27 (2018).

121. Johnson, D.J., et al. Climate sensitive size-dependent survival in tropical trees. Nature Ecology and Evolution doi.org/10.1038/s41559-018-0626-z (2018)

122. Pretzsch, H., Biber, P., Schütze, G., Uhl, E. and Rötzer, T., 2014. Forest stand growth dynamics in Central Europe have accelerated since 1870. Nature communications, 5 , p.4967.

123. Nicotra, A. B. et al. Plant phenotypic plasticity in a changing climate. Trends in Plant Sci. 15, 684-692 (2010).

124. Aitken, S. N., Yeaman, S., Holliday, J. A., Wang, T. \& Curtis-McLane, S. Adaptation, migration or extirpation: climate change outcomes for tree populations. Evol. Appl. 1, 95111 (2008).

125. Angert, A. L. et al. Do species' traits predict recent shifts at expanding range edges? Ecol. Lett. 14, 677-689 (2011).

126. Miller, K.M. and McGill, B.J., 2018. Land use and life history limit migration capacity of eastern tree species. Glob. Ecol. Biogeog., 27(1), pp.57-67

127. Slot, M. \& Katajima, K. General patterns of acclimation of leaf respiration to elevated temperatures across biomes and plant types. Oecologia 177, 885-900 (2015).

128. Rieu, P. B., Twell, D. \& Frion, N. Pollen development at high temperature: from acclimation to collapse. Plant Physiology 173, 1967-1976 (2017).

129. Adams, H. D. et al. Experimental drought and heat can delay phenological development and reduce foliar and shoot growth in semiarid trees. Glob. Chang. Biol. 21, 4210-4220 (2015).

130. Grossiord, C. et al. Warming combined with more extreme precipitation regimes modifies the water sources used by trees. New Phytol. 213, 584-596 (2017).

131. McLachlan, J. S., Hellmann, J. J. \& Schwartz, M. W. A framework for debate of assisted migration in an era of climate change. Conservation Biol. 21, 297-302 (2007).

132. Lloret, F., Escudero, A., Iriondo, J. M., Martínez-Vilalta, J. \& Valladares, F. Extreme climatic events and vegetation: the role of stabilizing processes. Glob. Chang. Biol. 18, 797-805 (2012).

133. Kemp KB, Higuera PE, Morgan P (2015) Fire legacies impact conifer regeneration across environmental gradients in the U.S. northern Rockies. Landsc Ecol 1-18. 133. Isbell, F. et al. Biodiversity increases the resistance of ecosystem productivity to climate extremes. Nature 526, 574-577 (2015). 
134. Thom, D., Rammer, W. \& Seidl, R. The impact of future forest dynamics on climate: interactive effects of changing vegetation and disturbance regimes. Ecol. Monogr. 87, 665684 (2017).

135. Powell, T. L. et al. Variation in hydroclimate sustains tropical forest biomass and promotes functional diversity. New Phytol. 219, 932-946 (2018).

136. Bonan, G. B. Forests and climate change: forcings, feedbacks, and the climate benefits of forests. Science 320, 1444-1449 (2008).

137. Luyssaert, S., Schulze, E.D., Börner, A., Knohl, A., Hessenmöller, D., Law, B.E., Ciais, P. and Grace, J., 2008. Old-growth forests as global carbon sinks. Nature, 455(7210), p.213.

138. Harmon, M.E., 2001. Carbon sequestration in forests: addressing the scale question. Journal of Forestry, 99(4), pp.24-29.

139. Pretzsch, H., Biber, P., Schütze, G., Uhl, E. and Rötzer, T., 2014. Forest stand growth dynamics in Central Europe have accelerated since 1870. Nature Communications, 5, p.4967.

140. Campbell, J.E., Berry, J.A., Seibt, U., Smith, S.J., Montzka, S.A., Launois, T., Belviso, S., Bopp, L. and Laine, M., 2017. Large historical growth in global terrestrial gross primary production. Nature, 544(7648), pp.84-87.

141. Randerson, J. T. et al. The impact of boreal forest fire on climate warming. Science 314, 1130-1132 (2006).

142. Lee, X., et al. Observed increase in local cooling effect of deforestation at higher latitudes. Science 479, 384-387 (2011).

143. Devaraju, N., Bala, G. \& Modak, A. Effects of large-scale deforestation on precipitation in the monsoon regions: Remote versus local effects. Proceedings of the National Academy of Sciences 112, 201423439 (2015).

144. Lejeune, Q., Davin, E. L., Guillod, B. P. \& Seneviratne, S. I. Influence of Amazonian deforestation on the future evolution of regional surface fluxes, circulation, surface temperature and precipitation. Climate Dynamics 44, 2769-2786 (2015).

145. Le Page, Y., Morton, D., Bond-Lamberty, B., Pereira, J.M.C. and Hurtt, G., 2015. HESFIRE: a global fire model to explore the role of anthropogenic and weather drivers. Biogeosciences

146. McDowell, N. G. et al. Evaluating theories of drought-induced vegetation mortality using a multimodel-experiment framework. New Phytol. 200, 304-321 (2013).

147. Lawrence, D., Hurtt, G., Arneth, A., Brovkin, V., Calvin, K., Jones, A., Jones, C., Lawrence, P., Noblet-Ducoudré, N., Pongratz, J., Seneviratne, S., Shevliakova, E. (2016). The Land Use Model Intercomparison Project (LUMIP) contribution to CMIP6: rationale and experimental design. Geoscientific Model Development 9(9), 2973 - 2998.

148. Simard, M., Pinto, N., Fisher, J. B. \& Baccini, A. Mapping forest canopy height globally with spaceborne lidar. J. Geophys. Research: Biogeosciences 116, G4 (2011). 
901
149. Lehsten, V., Mischurow, M., Lindström, E., Lehsten, D. \& Lischke, H. LPJ-GM 1.0: simulating migration efficiently in a dynamic vegetation model. Geosci. Model Dev. 12, 893-908 (2019).

150. Smith, B., Prentice, I. C. \& Sykes, M. T. Representation of vegetation dynamics in the modelling of terrestrial ecosystems: comparing two contrasting approaches within European climate space. Glob. Ecol. Biogeog. 10, 621-637 (2001).

151. Fisher, R. A. et al. Taking off the training wheels: the properties of a dynamic vegetation model without climate envelopes, CLM4.5(ED). Geoscientific Model Development 8, 3593-3619 (2015).

152. Chen, Y. et al. Simulating Damage for Wind Storms in the Land Surface Model ORCHIDEE-CAN (Revision 4262). Geosci. Model Dev. 8, 3593-3619 (2018).

153. Henkel, T. K., Chambers, J. Q. \& Baker, D. A. Delayed tree mortality and Chinese tallow (Triadica sebifera) population explosion in a Louisiana bottomland hardwood forest following Hurricane Katrina. For. Ecol. Manage. 378, 222-232 (2016).

154. Roccaforte, J. P. et al. Delayed tree mortality, bark beetle activity, and regeneration dynamics five years following the Wallow Fire, Arizona, USA: Assessing trajectories towards resiliency. For. Ecol. Manage. 428, 20-26 (2018).

155. Kennedy, D. et al. Implementing plant hydraulics in the Community Land Model, version 5. J. Adv. Modeling Earth Systems 11, 485-513 (2019).

156. Grubb, P.J. The maintenance of species-richness in plant communities: the importance of the regeneration niche. Biol. Rev. 52, 107-145 (1977).

157. Amiro, B. D. et al. Ecosystem carbon dioxide fluxes after disturbance in forests of North America. J. Geophys. Research: Biogeosciences 115, G4 (2010).

158. Hicke, J. A. et al. Effects of biotic disturbances on forest carbon cycling in the United States and Canada. Glob. Chang. Biol. 18, 7-34 (2012).

159. Grime, J. P. Plant strategies and vegetation processes (University of Michigan, Ann Arbor, 1979).

160. Jentsch, A. and White, P. A theory of pulse dynamics and disturbance in ecology. Ecol. 100(7) p.e02734.

161. Olson, D. M., Dinerstein, E., Wikramanayake, E. D., Burgess, N. D., Powell, G. V. N., Underwood, E. C., D'Amico, J. A., Itoua, I., Strand, H. E., Morrison, J. C., Loucks, C. J., Allnutt, T. F., Ricketts, T. H., Kura, Y., Lamoreux, J. F., Wettengel, W. W., Hedao, P., Kassem, K. R. 2001. Terrestrial ecoregions of the world: a new map of life on Earth. Bioscience 51(11):933-938. 
903 Acknowledgements: This manuscript was derived from the Department of Energy 904 Workshop "Disturbance and vegetation dynamics in Earth System Models" held in March 9052018 in Washington DC. Support was provided as follows: NGM the Department of 906 Energy's Next Generation Ecosystem Experiment-Tropics (NGEE-Tropics) and Pacific 907 Northwest National Lab's LDRD program, BA McIntire-Stennis MIN-17-095, CDA the U.S. 908 Geological Survey's Ecosystems and Land Resources mission areas, MGT the Joint Fire Science 909 Program (16-3-01-4) and the University of Wisconsin-Madison Vilas Trust, JL sabbatical 910 fellowship support from sDiv, the Synthesis Centre of iDiv (DFG FZT 118), CX DOE's NGEE911 Tropics and the Univerisity of California's Laboratory Fees Research Program (grant no. LFR912 18-542511), TP the European Research Council (ERC) under the European Union's Horizon 9132020 research and innovation programme (grant agreement no. 758873, TreeMort), Paper 914 number 43 of the Birmingham Institute of Forest Research, BBL PNNL's LDRD program, GH 915 and BP the NASA Carbon Monitoring System and NASA Interdisciplinary Science Programs. 916 Oak Ridge National Laboratory is operated by UT-Battelle, LLC, under contract DE-AC05917 00OR22725 to the United States Department of Energy. NM conceived of the manuscript layout; 918 all authors contributed to the literature survey and writing, TP with BP and GH conducted the 919 global analyses. All data are available 10.5281/zenodo.3698178 


\section{$\underline{\text { Box } 1 \text { Vegetation dynamics definitions }}$}

923 We focus on three main plant demographic processes: recruitment, growth, and mortality.

924 Recruitment (including reproduction) results in the seedling and sapling composition of a plant community following disturbance (156). Growth from sapling to mature plants results in development of mature forests and includes competitive processes. Mortality is a key rate controlling carbon storage and species composition in a plant community and is a dominant

928 demographic rate during a pulse-disturbance $(157,158)$.

929 Abiotic drivers. Physical factors that cause changes in demography and that respond to global 930 change or to disturbances, such as light, $\mathrm{CO}_{2}$, soil moisture, humidity, temperature, etc.

Biotic drivers. Biological factors that may drive changes in demography, such as pathogens, insects, herbivores, or competition with other individuals.

Chronic environmental change. Persistently changing drivers of demographic rates. These drivers have a non-stable and directional trajectory, such as rising $\mathrm{CO}_{2}$, temperature, and VPD.

935

936

937

938

939

Demographic rate. Any individual-, population-, or community-level parameter that affects the age- and/or size-structure of a population or community, including rates of recruitment, growth, and death.

Demographic driver. An abiotic or biotic factor that, when undergoing a change itself, also leads to a change(s) in one or more demographic rates.

Disturbance. The destruction of live plant biomass in a discrete event $(159,160)$.

Disturbance regimes. Spatial and temporal characteristics of disturbances in a landscape over a long time period, including frequency, return interval, duration, intensity, severity, and size.

Growth. The rate of biomass production over time at the individual or ecosystem scale (i.e. Net Primary Production grams $\mathrm{C} \mathrm{m}^{-2} \mathrm{yr}^{-1}$ ).

Land-use and land-cover change. Anthropogenic shifts in forms of cultivation or in vegetation cover such as due to forestry, or conversion of woodlands to crop ecosystems.

Mortality. Defined herein as the complete loss of a plants' ability to reproduce and ultimately loss of cellular metabolism.

Recruitment. The rates of transition of plants from one size class into another (typically in units of individuals $\mathrm{m}^{-2} \mathrm{yr}^{-1}$ ). Recruitment results from the birth and growth of individuals. Herein we consider recruitment from the stage of seed dispersal through seedling growth into the sapling stage.

Self-thinning. Reduction in the number of live plants within a stand, occurring via competition for resources.

Vegetation dynamics. The net outcome of the interplay between disturbances and vegetation demographic rates. 


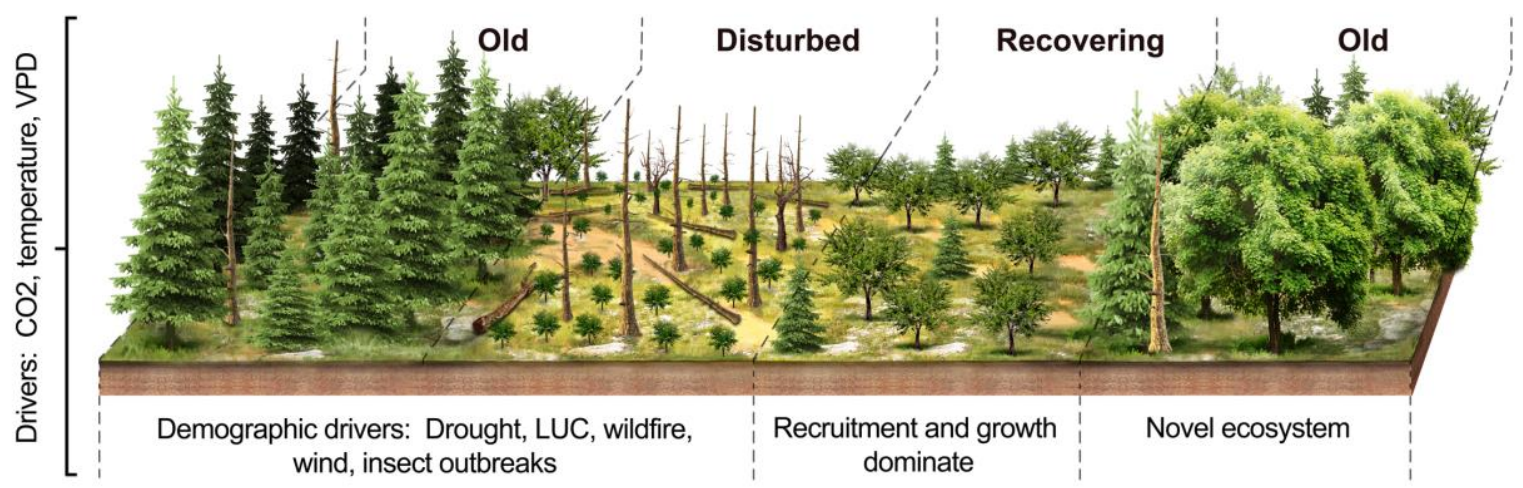

Figure 1. A conceptual diagram of the components of forest dynamics and disturbances that drive them. In the far-left panel, a mature ecosystem is responsive primarily to localized mortality, and the primary drivers of demography are chronically changing variables such as $\mathrm{CO}_{2}$, temperature, and $V P D$. The system is disturbed in the second panel, due to fire, insect outbreak, or another large-scale perturbation that removes much of the overstory trees, and species adapted to rapid post-disturbance recruitment become established. In the third panel recruitment and growth dominate demographic processes, with mortality increasing over time as competition leads to self-thinning. In the last panel, a mature ecosystem is dominated by species that have replaced the original community in response to chronic environmental changes, leading

969 to a novel ecosystem. 

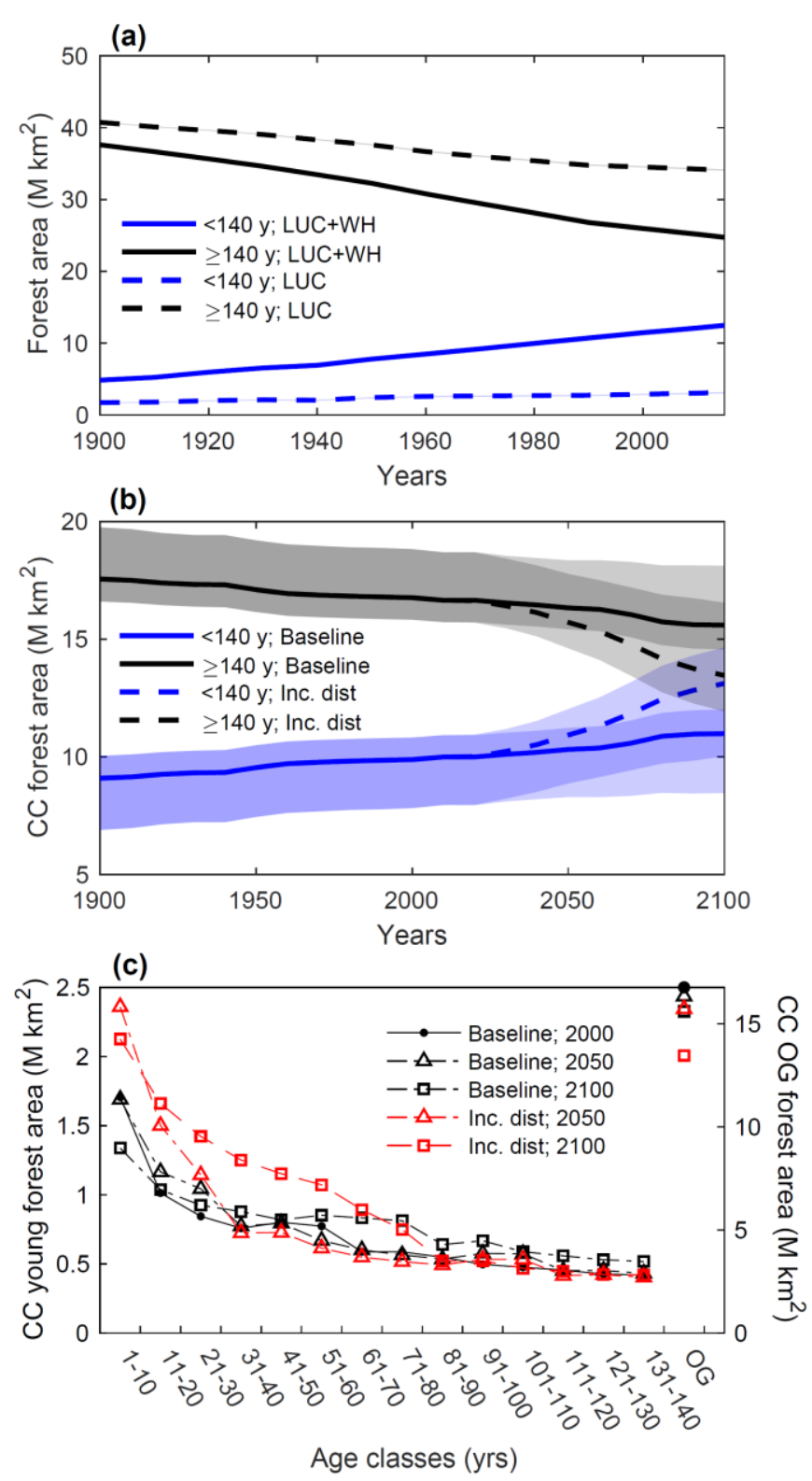

Figure 2. (a) Human activities have increased the amount of young forest area (stands $<140$ years old) over the $20^{\text {th }}$ century as a result of both landuse change (LUC) and wood harvest $(\boldsymbol{W H})$. Forest stand age distribution was reconstructed using forest-cover transitions from $L U H v 2$, initialized using forest cover fractions in 1750 and incrementing forest cover each year, tracking the age of forest up to 140 years. Solid lines show the effect of $L U C$ and $W H$, dashed lines $L U C$ alone. Total forest area is based on LUHv2. The nominal minimum size of a stand is assumed to be $c a$. 0.1 ha. (b) Sensitivity of age distribution in closed-canopy (CC) forests to plausible changes in disturbance rate. Forest stand age distribution was reconstructed using forest cover transitions due to $L U C$ from $L U H v 2$ alongside non- $L U C$ observation-based disturbance rates (25). In the baseline scenario (solid lines), non- $L U C$ disturbance is assumed constant at observed 2001-2014 values throughout. In the Inc. dist scenario (dashed lines), disturbance rates are incremented linearly to $200 \%$ of the 20012014 values over the period 2015 to 2050 and held constant at that level thereafter. The underlying $L U C$ scenario is GCAM RCP 3.4 that includes land-based mitigation for $\mathrm{CO}_{2}$ emissions. Results are presented for closed-canopy forests only (25), which is why total forest area is lower between (a) and (b), as non- $L U C$ disturbance rate information is not currently available for

open-canopy forests. The shaded areas in panels $\mathbf{a}$ and $\mathbf{b}$ indicate the effect of assuming that disturbances are five times more likely to affect the youngest forests versus old-growth, or vice versa, as opposed to an even probability across ages (solid lines). The apparent large dampening of this assumption in $\mathbf{a}$ vs $\mathbf{b}$ is primarily due to the different $y$-scales. (c) Changes in the disturbance regime propagate through forest age structure at decadal time scales. Closed-canopy young ( $<140$ years old) forest area is shown on the left-hand y-axis. Old-growth (>140 years old; OG) forest area is shown on the right axis (same units) and refers to the data points in the upper right-hand of the panel. Scripts used and additional methods can be accessed at https://github.com/pughtam/AgeClassReconst rel.git. 
1017 Figure 3. Human activities have increased the amount of young forest area irrespective of biome. 1018 As for Figure 2a, but broken down by biome ${ }^{161}$.
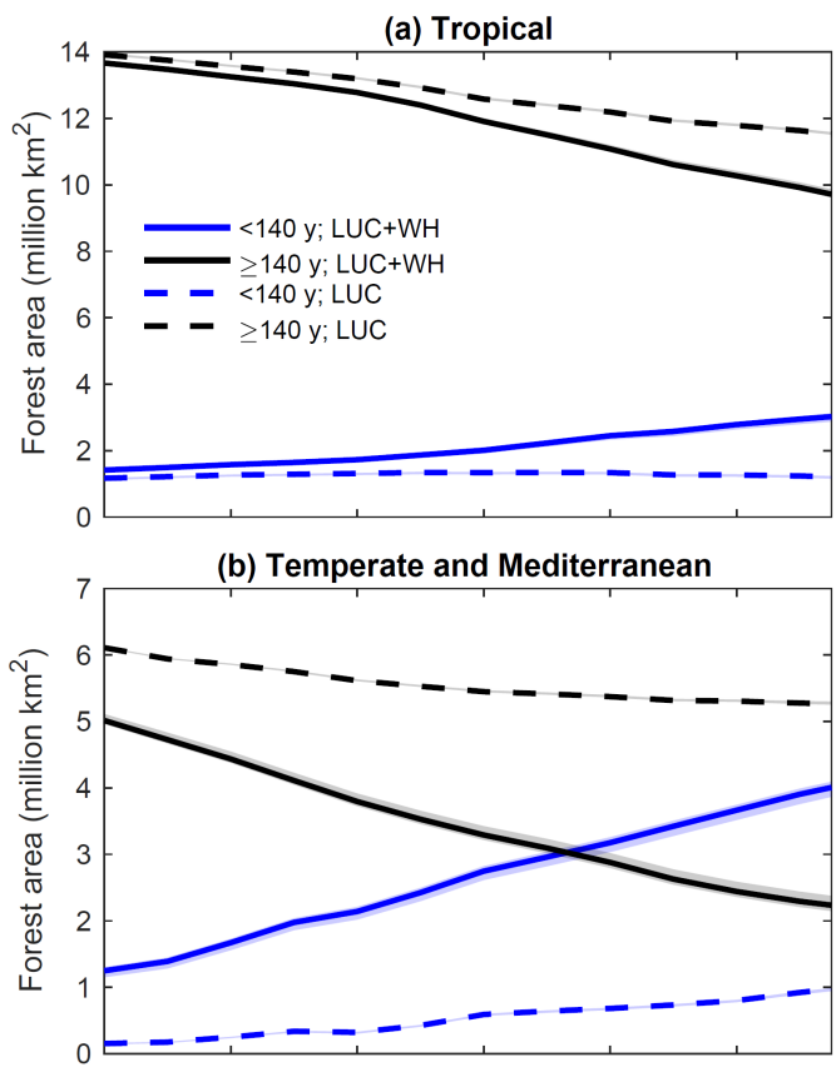

(c) Boreal

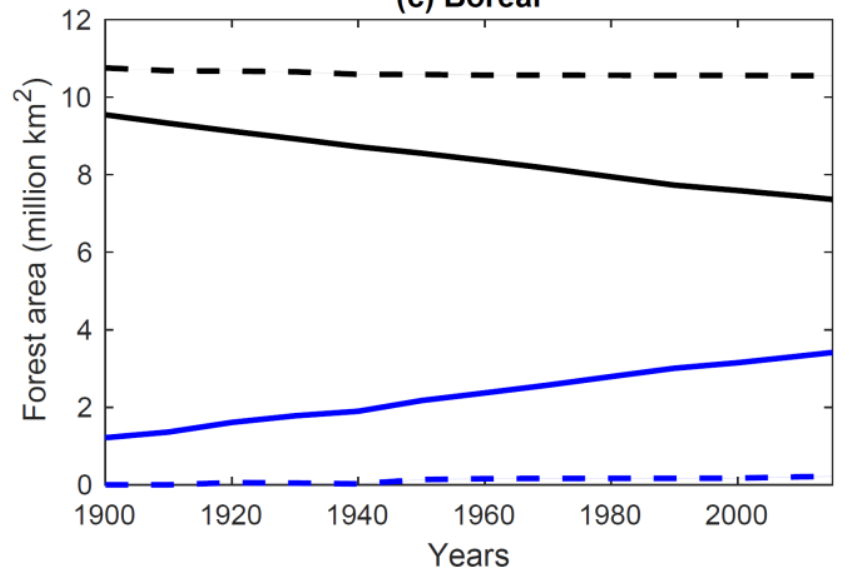


1022

1023

1024

1025

1026

1027

1028

1029

1030

\section{DRIVERS \& DISTURBANCES DEMOGRAPHIC RATES}

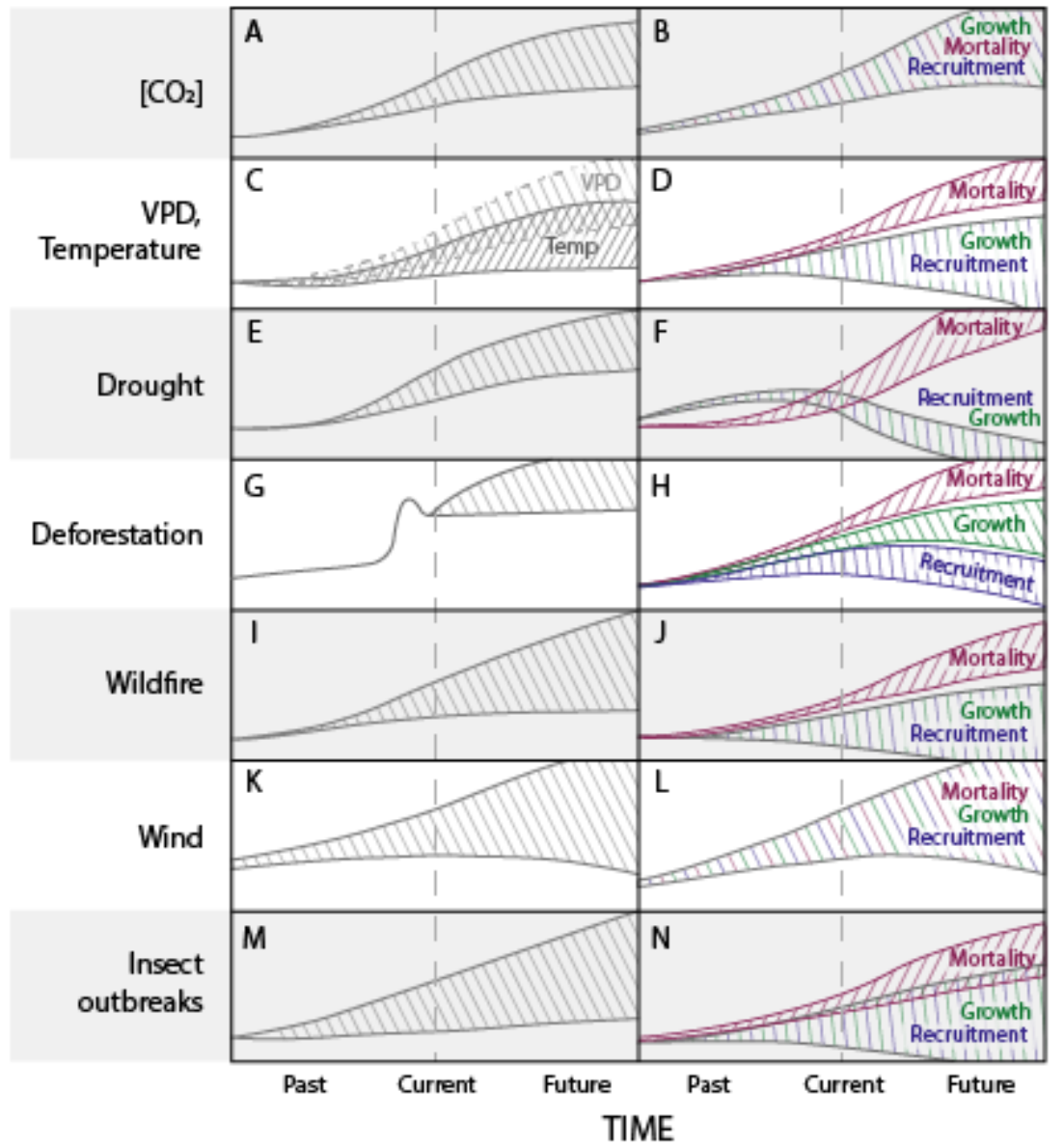

Figure 4. Drivers, disturbances, and demographics are changing both historically and into the future. A graphical summary of the literature evidence of changing drivers and disturbances (left-hand column) and subsequent demographic rates (right-hand column). Shown are the chronically changing drivers A) $\left.\mathrm{CO}_{2}, \mathrm{C}\right) \mathrm{VPD}$ and temperature and the more transient disturbances of E) drought (low precipitation), G) deforestation, I) wildfire, K) wind, and M) insect outbreaks. Each driver or disturbances' corresponding demographic responses (shown as carbon fluxes per area ${ }^{-1}$ time $^{-1}$ ) are shown on the right-hand panels. 


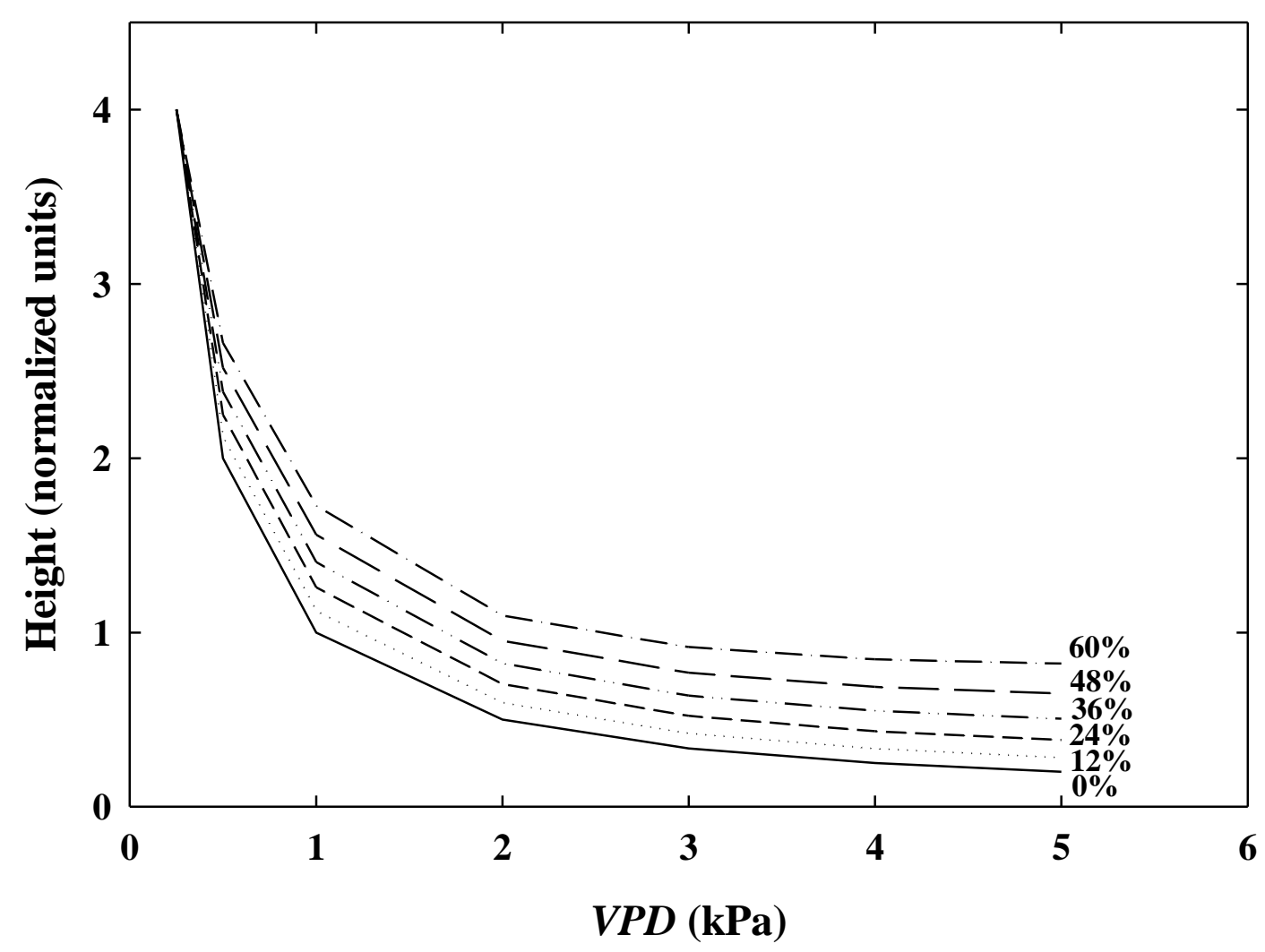

1031

1032 Figure 5. Rising VPD forces declines in potential plant stature. Predictions of plant height in 1033 response to rising $V P D$ from the hydraulic corollary to Darcy's law. The equation is $h=$ $1034 A_{\mathrm{s}} * \mathrm{k}_{\mathrm{s}} *(\Delta \Psi) / G^{*} A_{\mathrm{l}} * V P D$, where $h$ is height, $A_{\mathrm{s}}$ is sapwood area, $\mathrm{k}_{\mathrm{s}}$ is specific conductivity, $\Delta \Psi$ is 1035 the leaf to soil water potential gradient, $G$ is stomatal conductance, and $A_{1}$ is leaf area ${ }^{53}$. The 1036 different lines represent different levels of acclimation of $A_{\mathrm{s}}, \mathrm{k}_{\mathrm{s}}, \Delta \Psi, G$, and $A_{\mathrm{l}}$, all allowed to 1037 adjust simultaneously from 0 to $60 \%$ from their initial values. In the case of $G$ it is assumed to 1038 decrease due to rising atmospheric $\mathrm{CO}_{2}$. Acclimation can help, but not completely mitigate, the 1039 impacts of rising VPD on plant size. 